\section{International Scientific Journal Theoretical \& Applied Science}

p-ISSN: 2308-4944 (print) e-ISSN: 2409-0085 (online)

Year: 2017 Issue: $05 \quad$ Volume: 49

Published: 30.05.2017 http://T-Science.org

SECTION 9: Chemistry and chemical technology.
Oleg Ivanovych Yurchenko $\mathrm{PhD}$, Full Professor of Chemical Metrology Department, Kharkiv V.N. Karazine National University, yurchenko@karazin.ua

Alexandr Nikolaevych Baklanov PhD, Full Professor

of Chemical Metrology Department, Kharkiv V.N. Karazine National University, baklanov227@mail.ru

Tetyana Vasylivna Chernozhuk $\mathrm{PhD}$, Associate Professor of Inorganic Chemistry Department, Kharkiv V.N. Karazine National University, tanya.chernozhuk@gmail.com

Larysa Vladimirovna Baklanova $\mathrm{PhD}$, Researcher

of Chemical Metrology Department, Kharkiv V.N. Karazine National University, baklanov227@mail.ru

Oleksii Andriovych Kravchenko $\mathrm{PhD}$, Associate Professor of Chemical Metrology Department, Kharkiv V.N. Karazine National University, alekseykravch@ukr.net

\title{
ELECTROTHERMIC ATOMIC-ABSORPTION DETERMINATION OF LEAD AND CADMIUM IN FOOD USING TWO-FREQUENCY ULTRASOUND
}

Abstract: Use of simultaneous influence of ultrasound of high and low frequencies to intensificate possesses of wet mineralization of various kind of food was studied. It was shown that use of simultaneous influence of ultrasound of high and low frequencies let us, compare with use only ultrasound in low frequency, to increase extraction degree, to use only one oxidizer for all kinds of food, and let to develop unified methodic of electrothermic atomic-absorption determination of lead and cadmium in various kinds of food.

Key words: ultrasound, mineralization, extraction degree.

Language: English

Citation: Yurchenko OI, Baklanov AN, Chernozhuk TV, Baklanova LV, Kravchenko OA (2017) ELECTROTHERMIC ATOMIC-ABSORPTION DETERMINATION OF LEAD AND CADMIUM IN FOOD USING TWO-FREQUENCY ULTRASOUND. ISJ Theoretical \& Applied Science, 05 (49): 201-206.

Soi: http://s-o-i.org/1.1/TAS-05-49-30 Doi: crossef https://dx.doi.org/10.15863/TAS.2017.05.49.30

\section{Introduction}

Ultrasound (US) is used to intensify the most prolonged stadium of analysis of food -mineralization that takes more than $90 \%$ of time of the analysis. We use US for intensification of minerals by dry as well as wet methods [1,c.11;4,c.159].

To intensify dry mineralization, US was used only to create effect of boiling layer, and due to it, every particle of foods carbonizate was undergone by influence of oxidizers in vapor phase. Due to the fact, an express of the analysis was increased in 10-12 times compared to classic variant of dry mineralization [2,c.99;3,c.124].

More effective is use of US for intensification of wet mineralization [1,c.14]. We investigated the use of ultrasound (US) of frequency from 18 up to 100 $\mathrm{MHz}$. When using it, mineralization time decreased in 10-20 times, depending on the type of food, and extraction degree of lead and cadmium was 94-98\% [1,c.15].

We investigated before the use of simultaneous influence of US of high and low frequencies to 
intensify acidic extraction of lead and cadmium from fats and oils. It was shown that the use of simultaneous influence of US of high and low frequencies let us to decrease energetic intensity of the analysis due to decrease of intensity of US and to make better metrological characteristics of the results of analysis [5,c.127]. Also we investigated simultaneous influence of US of high and low frequencies to intensify sample preparation at analysis of sugar and products based on it to find out lead, copper and cadmium in it. At the analysis US was used to transfer compounds of lead, copper and cadmium in kinetically labile ones, and due to it, its extraction in form of diethyldithiocarbomates in chloroform from sugar solutions with concentration up to $100 \mathrm{~g} / \mathrm{l}$ is possible [4, c.160].

The main purpose of the work is to study simultaneous influence of US of high and low frequencies to intensify possessions of food wet mineralization and to develop unified methodic of determination of lead and cadmium in food of plant and animal origin.

\section{Experimental}

To produce fluctuations in low frequency tubular magnetostriction emitters were used. A test tube with investigated solution was placed into the emitters. On the high top of the test tube ring shaped piezoelectric emitter (with work frequency 1 or $2 \mathrm{MHz}$ ) of ZTL-19, made from titanium zirconate-lead was put on. Magnetostriction emitter was united with modernized ultrasound dispergator UZDN-1M, what led us to create the investigated solutions ultrasound fluctuations of frequency from 18 up to $44 \mathrm{kHz}$ and intensity from 0,05 up to $15 \mathrm{~W} / \mathrm{cm}^{2}$ (was limited by durability of the test tube). Supplement of piezoelectric emitter was done by the use lamp generator 24-UZGI-K-1,2 which led us to produce in investigated solution ultrasound fluctuations of frequency from 1 up to $2 \mathrm{MHz}$ and intensity up to 12 $\mathrm{W} / \mathrm{cm}^{2}$ (was limited by the durability of emitter) [4,c.161].

Methodic of the experiment for analysis of meat (lean pork, low fat beef), juices, fruits, flour, coffee and vegetables. $4 \mathrm{ml}$ of juice or $0,50 \mathrm{~g}$ of flour, coffee, vegetables, fruits, meat was placed into test tube and poured by mixture $(1: 1) \mathrm{H}_{2} \mathrm{O}_{2}+\mathrm{HNO}_{3}$ (8 ml at analysis of juices and $10 \mathrm{ml}$ at analysis of vegetables, coffee or flour).

Methodic of the experiment at analysis of beer and cereals. $4 \mathrm{ml}$ of beer or $0,5 \mathrm{~g}$ of grinded cereals was placed into test tube and poured in $10 \mathrm{ml}$ of mixture, which consists of hydrogen peroxide and nitric acid $(1: 1)$.

Methodic of the experiment at analysis of milk products. The sample of product of 2,00 $\mathrm{g}$ mass (at analysis of milk, milk cream $8 \%$ and fermented milk products) or 1,00 g (at analysis of curds, dry and condensed milk, butter, milk cream with fats contain more than $8 \%$ ) was placed in test tube and poured by $3 \mathrm{ml}$ of nitric acid $(1: 1)$ in the first case; and by mixture from $3 \mathrm{ml}$ of nitric (1:1) and chloric (1:1) acids $(3: 1)$.

Methodic of the experiment at analysis of bakery. At analysis of sugar contained bakery (cake donetsky, cake with jam) sample of the product of 1,00 $\mathrm{g}$ mass was placed in test tube and poured in $6 \mathrm{ml}$ of mixture of nitric acid with hydroxide peroxide $(1: 1)$, and at analysis of bread by $6 \mathrm{ml}$ of nitric acid (1:1). The obtained mineralizate is poured by $1 \mathrm{ml} 0,001 \mathrm{mg} / \mathrm{l}$ solution of $\mathrm{Pd}\left(\mathrm{NO}_{3}\right)_{2}$, diluted by bidistilled water up to $10 \mathrm{ml}$ volume and content of lead and cadmium by flameless atomic-absorption method, according to [6,c.18] by temperature-time program [1,c.17]. is determined. The same samples were analyzed by atomic absorption standard method after mineralization by dry and wet methods [1,c.18]. at the same time. As a criteria of extraction fullness of the toxic elements the term "extraction degree", proposed in [1,c.20]. was used.

An extraction degree was determined by the next formulas:

$$
X=\frac{m}{N} \times 100
$$

where $m$ is an arithmetical mean of six measurements of contain of determined element by proposed method, $\mathrm{mg} / \mathrm{kg}$;

$$
n=\frac{p+g}{2}, m g \backslash k g
$$

where $p$ is an arithmetical mean of six measurements of contain of determined element, that obtained by atomic-absorption method after dry aching, $\mathrm{mg} / \mathrm{kg}$ [1,c.23]. ;

$g$ is an arithmetical means of six measurements that contains the determined element that is obtained by atomic-absorption method after mineralization, $\mathrm{mg} / \mathrm{kg}[6, \mathrm{c} .20]$.

\section{Results and discussion}

As a result of proper investigations it was established that at the use of simultaneous influence of US of high and low frequencies an extraction degree of lead and cadmium was higher (98-99 \%), than the use of only US of low frequency US (93-96 $\%$ ) during extraction, using optimal oxidizers, selected for every type of food (pointed out above in the method of experiments) [4,c.164]. (table 1). Frequency change of US of low frequency from 18 to $47 \mathrm{kHz}$ did not make influence on the value of extraction degree, compare to the results, obtained by using the US with high frequency ( 1 and $2 \mathrm{MHz}$ ), what shows us that better results were obtained in the first case (table 2). Optimal intensity of US with high frequency and with low one depends on the type of food product, intensity of high-frequency US did not 
exceed 2,0 W/sm ${ }^{2}$ for high-frequency and $2,5 \mathrm{~W} / \mathrm{sm}^{2}$ for low-frequency (table 2). As "optimal intensity" we considered intensity that supply maximal possible value of analytic signal. It should be pointed out that optimal intensity with the use of only US of low frequency was more higher (from 3,5 $\mathrm{W} \backslash \mathrm{sm}^{2}$ for juices up to $\mathrm{W} \backslash \mathrm{sm}^{2}$ for milk products). Time of influence of two frequency US should be not less than 1 minute for juices, 2 minutes for food of plant origin and 3 minutes for food of animal origin, using, as oxidizer, hydrogen peroxide. An order to switch on US of high and low frequencies made no influence on obtained results.

More higher efficiency of simultaneous influence of US of high and low frequencies can be explained by the peculiarities of the formation and breaking of cavitation bubbles at two frequencies US influence, when small spherical cavitation bubbles forms, and at its breaking, sound chemical reactions, laid on the base of mineralization processes, are intensified [7,c.33; 8,c.24].

Frequency change of low frequency US from 18 to $100 \mathrm{kHz}$ did not make influence on extraction degree of betha-carotine. Comparison of the results, obtained using high frequency US (1-5 MHz), shows that the best results were obtained using US with frequency 1,0-2,5 $\mathrm{MHz}$ (table 2), intensity 1,5-2,5 $\mathrm{W} / \mathrm{cm}^{2}$ for low frequency and $2,5-4,0 \mathrm{~W} / \mathrm{cm}^{2}$ for high frequency (table 2), and time should be not less than 2 min.

\section{Conclusions}

Therefore, use of simultaneous influence of ultrasound of high and low frequencies let us, compare to the use of only US with low frequency, to increase an extraction degree, to use only one oxidizer for all types of food, and to develop unified methodic to analyze food. More higher efficiency of simultaneous influence of US of high and low frequencies compared to US only of low frequencies can be explained by prevalence of total mass of the small spherical bubbles, that promote sound chemical reactions, in the first case, upon big deformation bubbles, that promote mass exchange possesses, dispergation, emulgation [9,c.60;10,c.95]. Unified methodic of lead and cadmium determination in various food was developed. The accuracy of the method was checked by analysis of the same samples by standard method (table 4).

Unified methodic of lead and cadmium determination in food of plant and animal origin.

Sample of food by animal origin of $0,50 \mathrm{~g}$, or plant origin of $1,00 \mathrm{~g}$ placed into test tube and poured in $5 \mathrm{ml}$ of hydrogen peroxide. $(90 \%)$. The test tube is placed in magnetostriction emitter and affected by US with frequencies in $22 \mathrm{\kappa Hz} \mathrm{и} 1 \mathrm{MHz}$ and intensity 2,0 и $2,5 \mathrm{~W} / \mathrm{cm}^{2}$ correspondingly. Time of US influence at analysis of food of plant origin is 2 minutes, and 3 minutes for food of animal origin.

Obtained mineralizate is poured by $1 \mathrm{ml}$ of $0,001 \mathrm{mg} / 1$ solution of $\mathrm{Pd}\left(\mathrm{NO}_{3}\right)_{2}$, diluted by distilled water up to $10 \mathrm{ml}$ volume and content of lead and cadmium by flameless atomic-absorption method, by temperature-time program is determined [3,c.124].

Table 1

Extraction degree of lead and cadmium from various food products at simultaneous influence of US of high and low frequencies and US of low frequency.

\begin{tabular}{|c|c|c|c|c|}
\hline \multirow{3}{*}{ Type of food } & \multicolumn{4}{|c|}{ Extraction degree, $\%$} \\
\hline & \multicolumn{2}{|c|}{$\begin{array}{c}\text { simultaneous influence of US of } \\
\text { high and low frequencies }\end{array}$} & \multicolumn{2}{|c|}{ US of low frequency } \\
\hline & Lead & Cadmium & Lead & Cadmium \\
\hline 1 & 2 & 3 & 4 & 5 \\
\hline Meat (beef) & 99 & 98 & 94 & 93 \\
\hline Meat (pork) & 99 & 98 & 95 & 93 \\
\hline Milk, fat content $2,5 \%$ & 99 & 99 & 96 & 95 \\
\hline Milk, fat content $3,2 \%$ & 99 & 99 & 95 & 93 \\
\hline Milk cream, fat content $10 \%$ & 99 & 98 & 93 & 94 \\
\hline Milk cream, fat content $20 \%$ & 98 & 98 & 93 & 95 \\
\hline Flour of high quality & 99 & 98 & 93 & 93 \\
\hline Pearl barley & 99 & 99 & 96 & 94 \\
\hline
\end{tabular}




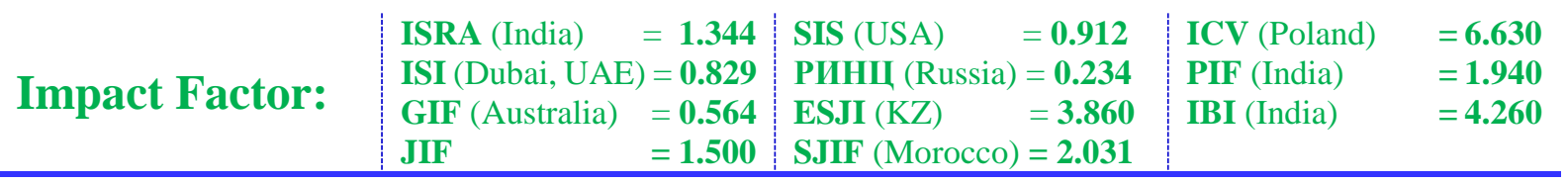

\begin{tabular}{|l|c|c|c|c|}
\hline & & & & \\
\hline Buckwheat & 99 & 99 & 96 & 95 \\
& & & 99 & 94 \\
\hline Bread «Dondassky New» & 99 & 99 & 97 & 95 \\
\hline Cake with jam & 98 & 99 & 95 & 96 \\
\hline Coffee & 98 & 98 & 96 & 96 \\
\hline Apples & 99 & 99 & 94 & 95 \\
\hline Cabbage & 99 & 98 & 96 & 95 \\
\hline Apricot juice & 98 & 98 & 95 & 96 \\
\hline Light beer "Obolon" & 98 & 98 & 94 & \\
\hline Beer "Chernigovskoe light” & 99 & & & 96 \\
\hline
\end{tabular}

Note. There are represented the average results of six experiments in the table and in the next ones. Mass of sample of the investigated product is $1,00 \mathrm{~g}$. Oxidizer is hydrogen peroxide, $5 \mathrm{ml}$. US parameters at simultaneous influence: frequency of high frequency-1 MHz, low frequency- $22 \mathrm{kHz}$, intensity of high frequency-2,0 W/sm ${ }^{2}$, low frequency$2,5 \mathrm{~W} / \mathrm{sm}^{2}$, time of influence $3 \mathrm{~min}$. At use only US of low frequency: frequency- $22 \mathrm{kHz}$, intensity $-7 \mathrm{~W} / \mathrm{sm}^{2}$, time of influence $7 \mathrm{~min}$.

Table 2

An influence of US frequency on extraction degree of lead and cadmium

\begin{tabular}{|l|c|c|c|c|}
\hline \multirow{2}{*}{ Type of food } & \multicolumn{4}{|c|}{ Extraction degree, \% } \\
\cline { 2 - 5 } & \multicolumn{3}{|c|}{$1 \mathrm{MHz}$} & \multicolumn{2}{c|}{$2 \mathrm{MHz}$} \\
\cline { 2 - 5 } Meat (beef) & 100 & 98 & 92 & 93 \\
\hline Meat (pork) & 100 & 98 & 93 & 91 \\
\hline Milk, fat content 2,5\% & 100 & 100 & 95 & 96 \\
\hline Milk, fat content 3,2\% & 100 & 100 & 92 & 93 \\
\hline Milk cream, fat content 10\% & 99 & 98 & 91 & 90 \\
\hline Milk cream, fat content 20\% & 98 & 98 & 89 & 84 \\
\hline Flour of high quality & 99 & 98 & 95 & 97 \\
\hline Pearl barley & 100 & 100 & 94 & 95 \\
\hline Buckwheat & 100 & 100 & 95 & 93 \\
\hline Bread «Dondassky New» & 100 & 100 & 97 & 95 \\
\hline Cake with jam & 98 & 100 & 91 & 90 \\
\hline Coffee & 98 & 100 & 94 & 91 \\
\hline Apples & 99 & 98 & 92 & 92 \\
\hline Cabbage & 100 & 99 & 95 & 94 \\
\hline Apricot juice & 98 & 98 & 94 & 94 \\
\hline Light beer “Obolon” & & & 90 & 91 \\
\hline
\end{tabular}

ISPC Technology and progress, 


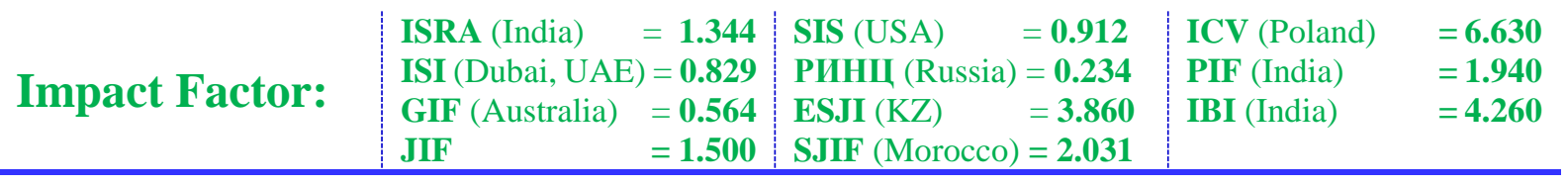

\begin{tabular}{|l|l|l|l|l|}
\hline Beer "Chernigovskoe light" & 99 & 98 & 92 & 93 \\
\hline
\end{tabular}

Intensity of US of high frequency-2,0 W/sm ${ }^{2}$, low frequency-2,5 W/sm², frequency of low frequency: US- $22 \mathrm{kHz}$ time of influence $3 \mathrm{~min}$.

Table 3

The value of optimal US intensity depends on the type of food product and US frequency

\begin{tabular}{|l|c|c|}
\hline \multirow{2}{*}{ Name of sample } & \multicolumn{2}{|c|}{ Optimal US , W/sm ${ }^{2}$} \\
\cline { 2 - 3 } & $1 \mathrm{MHz}$ & $22 \mathrm{~Hz}$ \\
\hline Meat (pork) & 1,8 & 2,0 \\
\hline Milk, fat content 2,5\% & 1,7 & 2,0 \\
\hline $\begin{array}{l}\text { Milk cream, fat content } \\
20 \%\end{array}$ & 2,0 & 2,5 \\
\hline Buckwheat & 1,5 & 1,8 \\
\hline Cake with jam & 1,6 & 2,0 \\
\hline Coffee & 1,5 & 2,0 \\
\hline Apples & 1,6 & 1,5 \\
\hline Apricot juice & 1,6 & 1,7 \\
\hline Beer "Donetskoe", 14\% & 1,8 & 2,0 \\
\hline
\end{tabular}

Table 4

Results of determination of lead and cadmium in various types of food

\begin{tabular}{|l|c|c|c|c|c|c|c|c|}
\hline \multirow{3}{*}{ Name of sample } & \multicolumn{7}{|c|}{ Found out, $\mathrm{mg} / \mathrm{kg}$; (n=6) } \\
\cline { 2 - 10 } & \multicolumn{7}{|c|}{ By proposed method } & \multicolumn{7}{c|}{ By standard method [1] } \\
\cline { 2 - 10 } & $\mathrm{Pb}$ & $\mathrm{S}_{\mathrm{r}}$ & $\mathrm{Cd}$ & $\mathrm{S}_{\mathrm{r}}$ & $\mathrm{Pb}$ & $\mathrm{S}_{\mathrm{r}}$ & $\mathrm{Cd}$ & $\mathrm{S}_{\mathrm{r}}$ \\
\hline \multirow{3}{*}{ Meat (beef) } & 0,195 & 0,06 & 0,037 & 0,08 & 0,192 & 0,09 & 0,035 & 0,10 \\
\hline Meat (pork) & 0,092 & 0,07 & 0,013 & 0,07 & 0,095 & 0,10 & 0,012 & 0,11 \\
\hline Milk, fat content 2,5\% & 0,114 & 0,07 & 0,020 & 0,07 & 0,116 & 0,10 & 0,018 & 0,10 \\
\hline Milk, fat content 3,2\% & 0,128 & 0,07 & 0,021 & 0,06 & 0,134 & 0,10 & 0,019 & 0,09 \\
\hline Milk cream, fat content 10\% & 0,160 & 0,06 & 0,020 & 0,07 & 0,155 & 0,09 & 0,022 & 0,10 \\
\hline Milk cream, fat content 20\% & 0,150 & 0,07 & 0,014 & 0,08 & 0,153 & 0,10 & 0,013 & 0,09 \\
\hline Flour of high quality & 0,066 & 0,07 & 0,041 & 0,07 & 0,061 & 0,10 & 0,036 & 0,09 \\
\hline Pearl barley & 0,085 & 0,07 & 0,053 & 0,06 & 0,081 & 0,10 & 0,048 & 0,10 \\
\hline
\end{tabular}




\begin{tabular}{|c|c|c|c|c|c|c|}
\hline Impact Factor: & $\begin{array}{l}\text { ISRA (India) } \\
\text { ISI (Dubai, UAE } \\
\text { GIF (Australia) } \\
\text { JIF }\end{array}$ & $\begin{array}{l}=1.344 \\
=0.829 \\
=0.564 \\
=1.500\end{array}$ & $\begin{array}{l}\text { SIS (USA) } \\
\text { PИНЦ (Russia } \\
\text { ESJI (KZ) } \\
\text { SJIF (Morocco }\end{array}$ & $\begin{aligned}= & 0.912 \\
= & 0.234 \\
= & 3.860 \\
= & \mathbf{2 . 0 3 1}\end{aligned}$ & $\begin{array}{l}\text { ICV (Poland) } \\
\text { PIF (India) } \\
\text { IBI (India) }\end{array}$ & $\begin{array}{l}=6.630 \\
=1.940 \\
=4.260\end{array}$ \\
\hline
\end{tabular}

\begin{tabular}{|l|c|c|c|c|c|c|c|c|}
\hline Buckwheat & 0,159 & 0,08 & 0,035 & 0,08 & 0,153 & 0,10 & 0,030 & 0,11 \\
\hline Bread «Dondassky New» & 0,217 & 0,07 & 0,019 & 0,08 & 0,211 & 0,10 & 0,018 & 0,09 \\
\hline Cake with jam & 0,114 & 0,06 & 0,029 & 0,08 & 0,114 & 0,09 & 0,027 & 0,09 \\
\hline Coffee & 0,157 & 0,06 & 0,014 & 0,08 & 0,153 & 0,09 & 0,012 & 0,10 \\
\hline Apples & 0,084 & 0,07 & 0,007 & 0,08 & 0,085 & 0,09 & 0,008 & 0,10 \\
\hline Cabbage & 0,079 & 0,07 & 0,009 & 0,08 & 0,071 & 0,11 & 0,011 & 0,10 \\
\hline Apricot juice & 0,129 & 0,07 & 0,019 & 0,08 & 0,122 & 0,09 & 0,021 & 0,10 \\
\hline Light beer “Obolon" & & & & & & & & \\
\hline Beer “Chernigovskoe light" & & & & & & & & \\
\hline
\end{tabular}

Note. At analysis of food products according to proposed methodic the main criteria were next. Mass of sample of the investigated product is $1,00 \mathrm{~g}$. Oxidizer is hydrogen peroxide, $5 \mathrm{ml}$. US parameters at simultaneous influence: frequency of high frequency-1 MHz, low frequency-22 kHz, intensity of high frequency-2,0 W/sm ${ }^{2}$, low frequency$2,5 \mathrm{~W} / \mathrm{sm}^{2}$, time of influence $3 \mathrm{~min}$. At use only US of low frequency: frequency- $22 \mathrm{kHz}$, intensity $-7 \mathrm{~W} / \mathrm{sm}^{2}$, time of influence $3 \mathrm{~min}$.

\section{References:}

1. Baklanov AN, Avdeenko AP, Konovalova SA, Baklanova LV (2012) 'Ultrazvuk V analyticeckoi himii I himicheskoi technologii '. DGMA, Kramatorsk, 332 p .

2. Yurchenko OI, Baklanov AN, Kalinenko OS, Belova YA, Baklanova LV, Larin VI (2015) Ukrainsky chimichny journal, T. 81, p.98-102.

3. Yurchenko OI, Baklanov AN, Kalinenko OS (2015) International Scientific Journal Theoretical \& Applied Science. Section 9. Chemistry and chemical technology, T.7, p.122129.

4. Yurchenko OI, Baklanov AN, Kalinenko OS, Belova YA, Baklanova LV (2016) International Scientific Journal Theoretical \& Applied Science. Section 9. Chemistry and chemical technology, T. 1, p. 158-163.
5. Yurchenko OI, Baklanov AN, Kalinenko OS (2014) Visnyk Kharkivskogo nationalnogo universytety 2014, T. 1136, p. 126-132.

6. (1986) GOST 26927-GOST 26935 - 86. Methody opredelenya toxiceckih elementov. USSR Industrial Standards Committee, Moscow USSR, $85 \mathrm{p}$.

7. Margulis MA (1986) Zvykovye chimicheskie reakcii i sonoluminiscencia . Chimia, Moscow USSR, 288 p.

8. Frydman VM (1976) Ultrazvykovoe himicheskoe oborudovanie, Mashinostroenie, Moscow, 193 p.

9. Vorontsov MA (2008) Journal prikladnoi chimii, T.81, p. 59-71.

10. Zivnov VA, Rumuanthev IY, Tomin VI (1976) Izvestia AN BSSR. T.3, p.91-103. 